BEN S. BERNANKE

Princeton University

JOHN Y. CAMPBELL

Princeton University

TONI M. WHITED

Board of Governors of the Federal Reserve System

\title{
U.S. Corporate Leverage: Developments in 1987 and 1988
}

THE YEARS 1987 and 1988 saw some dramatic developments in U.S. financial markets. The 1987 stock market crash was followed in 1988 by intense corporate restructuring activity, including a record volume of stock repurchases and leveraged buyouts. ${ }^{1}$ Meanwhile the use of debt financing by U.S. corporations continued to increase, even among firms not involved in ownership changes or major restructurings.

The increase in corporate leverage has caused some concern to policymakers responsible for the stability of the U.S. financial system. Federal Reserve Board Chairman Alan Greenspan testified in January 1989 to the Senate Finance Committee that "the spate of mergers, acquisitions, leveraged buyouts, share repurchases, and divestitures in

We are grateful to Eugene Wan for research assistance, to Mark Warshawsky for comments on an earlier draft, and to Steven Kaplan, Scott Mason, and the International Swap Dealers Association for information on the interest rate swap market. The views expressed in this paper are those of the authors and do not necessarily reflect the opinions of the Board of Governors or its staff.

1. Our focus is not on leveraged buyouts; for studies of LBOs, see Kaplan (1990); Lichtenberg and Siegel (1989a, 1989b); Marais, Schipper, and Smith (1989). Many firms have increased their use of debt without being involved in LBOs; indeed, Margaret Blair and Robert Litan (1989) find almost no correlation between increasing leverage and LBO activity in a sample of U.S. manufacturing industries. Our sample of firms excludes firms that have been taken private and thus is relatively uninformative about LBO activity. 
recent years is a significant development. ... While the evidence suggests that the restructurings of the 1980's probably are improving, on balance, the efficiency of the American economy, the worrisome and possibly excessive degree of leveraging associated with this process could create a new set of problems for the financial system." 2

This report updates the evidence in our earlier Brookings Panel paper on the changing capital structure of the U.S. corporate sector. ${ }^{3}$ As in that paper, our first objective is to characterize in detail the entire distribution of leverage across industries and individual firms. By using firm-specific information available on the COMPUSTAT data tapes, we go beyond the usual focus on aggregate numbers. We also assess the potential social costs and benefits of the increased leverage of recent years.

\section{The Changing Capital Structure of the U.S. Corporate Sector}

A standard source of information on the changing corporate capital structure is the system of Flow of Funds accounts produced by the Federal Reserve Board. According to the Flow of Funds, debt-asset ratios for the nonfinancial corporate sector (with debt measured at book value and equity at market value) rose from 0.40 in 1985 and 1986 to 0.42 in 1987 and 0.43 in 1988. Much of the increase was the result of firms swapping equity for debt; the Flow of Funds shows net equity repurchases of about $\$ 80$ billion in each of the years 1985, 1986, and 1987, increasing to just over $\$ 130$ billion in $1988 .{ }^{4}$ (Preliminary figures for 1989 show rates of debt issuance and equity repurchase almost identical to those for 1988.) The debt-asset ratio in 1988 is the same, after a six-year economic expansion, as the ratio in 1981 and is only 1 percentage point below the all-time high in 1975, both recession troughs. The recent increase in leverage is thus highly unusual at this stage of the business cycle.

In this report we concentrate on a different, disaggregated data source: the 1989 COMPUSTAT data tape, which gives accounting data for

2. Greenspan $(1989$, p. 1).

3. Bernanke and Campbell (1988). See also Warshawsky (1990) for a recent analysis in a similar spirit.

4. Board of Governors of the Federal Reserve System (1989). 
Table 1. Annual Growth Rates, COMPUSTAT Firms, 1987-88

Percent

\begin{tabular}{|c|c|c|c|c|c|c|}
\hline \multirow[b]{2}{*}{ Year } & \multirow[b]{2}{*}{ Sales } & \multirow[b]{2}{*}{$\begin{array}{l}\text { After-tax } \\
\text { earnings }\end{array}$} & \multirow[b]{2}{*}{$\begin{array}{l}\text { Interest } \\
\text { expense }\end{array}$} & \multicolumn{2}{|c|}{ Debt } & \multirow[b]{2}{*}{$\begin{array}{c}\text { Market } \\
\text { equity }\end{array}$} \\
\hline & & & & $\begin{array}{l}\text { Book } \\
\text { value }\end{array}$ & $\begin{array}{c}\text { Market } \\
\text { value }\end{array}$ & \\
\hline \multicolumn{7}{|c|}{ Full sample } \\
\hline 1987 & 10.7 & 38.1 & 2.0 & 4.5 & 2.7 & 2.7 \\
\hline 1988 & 9.4 & 13.0 & 8.3 & 6.5 & 4.5 & 8.4 \\
\hline \multicolumn{7}{|c|}{ Median firm (50th percentile) } \\
\hline 1987 & 9.2 & 36.9 & 3.6 & 1.6 & 1.2 & 2.0 \\
\hline 1988 & 10.3 & 11.3 & 8.9 & 2.5 & 5.1 & 5.4 \\
\hline
\end{tabular}

Source: Standard and Poor Corporation, Compustat Annual Industrial, Over-the-Counter, and Research Files. New York. 1989 edition. The sample consists of 1,179 firms for which all data are available in 1986, 1987, and 1988 on a consistent basis. (See the appendix for details.)

several thousand U.S. corporations. Our data set, which excludes firms that lack complete and consistently reported data for the years 1986, 1987, and 1988, includes almost 1,200 corporations. These companies, which had total sales of $\$ 2.3$ trillion and book debt outstanding of $\$ 675$ billion in 1988, include almost all the largest publicly traded U.S. corporations. $^{5}$

Details about the construction of our data set are given in the appendix, and a summary of the data appears in tables 1 and 2 . Table 1 reports growth rates in 1987 and 1988 of some important financial variables. Growth rates are reported both for the full sample (that is, treating all the companies as if they were a single firm and adding up the dollar quantities of each variable) and for the median firm.

Both 1987 and 1988 were years of steady growth in sales, with growth rates between 9 percent and 11 percent for the full sample and for the median firm. After-tax earnings grew more than 35 percent in 1987, but slowed down in 1988. Sales and earnings growth outpaced the growth in the book value of debt and interest expense in both years. Table 1 also shows growth rates for the market value of debt and equity. Not surprisingly, 1987 was a relatively poor year for equities, with less than 3 percent growth in market value. In 1988 the stock market rebounded,

5. See table 2. Firms that have been taken private are excluded from the sample. However, we do not believe that this is an important source of bias in this or our previous study. See the appendix for evidence on this point. 
Table 2. Sources and Uses of Funds, COMPUSTAT Firms, 1986-88

Billions of current dollars

\begin{tabular}{|c|c|c|c|c|c|c|c|}
\hline \multirow[b]{2}{*}{ Year } & \multicolumn{2}{|c|}{ Sources } & \multicolumn{3}{|c|}{ Uses } & \multicolumn{2}{|c|}{ Reference } \\
\hline & $\begin{array}{l}\text { After-tax } \\
\text { earnings }\end{array}$ & $\begin{array}{c}\text { Net debt } \\
\text { issue }\end{array}$ & $\begin{array}{l}\text { Net equity } \\
\text { repurchase }\end{array}$ & $\begin{array}{c}\text { Total } \\
\text { dividends }\end{array}$ & Other & Sales & $\begin{array}{l}\text { Book } \\
\text { debt }\end{array}$ \\
\hline 1986 & 82.7 & 47.5 & 5.2 & 53.4 & 71.6 & 1,914 & 606.6 \\
\hline 1987 & 114.3 & 27.3 & 8.1 & 64.4 & 69.2 & 2,118 & 633.9 \\
\hline 1988 & 129.2 & 40.9 & 26.0 & 73.0 & 71.1 & 2,316 & 674.9 \\
\hline
\end{tabular}

Source: 1989 COMPUSTAT tape. The sample consists of 1,179 firms for which all data are available in 1986 , 1987, and 1988 on a consistent basis. (See the appendix for details.)

with more than 8 percent growth for the full sample and more than 5 percent growth for the median firm. The market value of debt grew slightly less than the market value of equity in each year.

Table 2 shows the levels of some key variables for the full sample in 1986, 1987, and 1988. The dramatic growth in earnings in 1987 shows up again in this table. The table also reinforces the Flow of Funds evidence that 1988 was a record year for net equity repurchases. In the COMPUSTAT sample, net repurchases totaled $\$ 26$ billion in 1988, more than three times the 1987 volume.

Tables 1 and 2 give the impression that U.S. corporate leverage was stable or decreasing in 1987 and 1988, thus contradicting the aggregate numbers from the Flow of Funds accounts. Our sample appears to be a conservative one that understates the changes taking place in the corporate sector as a whole. ${ }^{6}$

Even in our sample, however, the leverage of the most highly levered firms continued to increase in 1987 and 1988. In table 3 we summarize the cross-sectional distribution of various measures of leverage, giving values for the full sample, for the median firm (50th percentile), and for firms at the 90th, 95th, and 99th percentiles of the distribution.

We begin with a "stock" concept of the debt burden, the ratio of the market value of debt to the total market value of the corporation. This ratio is not a straightforward measure because the market value of debt is not reported on the COMPUSTAT tape, but must be imputed. Our two techniques for doing this, which we call Method A and Method B,

6. Below we compare our data with industry balance sheet data from the Quarterly Financial Reports, published by the Department of Commerce. This comparison also suggests that our sample understates the overall increase in corporate leverage. 
are discussed in detail in our earlier paper. ${ }^{7}$ For the full sample, both methods show slowly declining debt-asset ratios during 1986-88, but the median and higher percentiles of the distribution all increase.

Table 3 also shows some "flow" concepts of debt burden using three measures: interest expense relative to cash flow (operating income before depreciation, interest, and taxes are deducted), interest expense relative to a three-year moving average of cash flow, and interest expense relative to current assets.

The full sample interest expense-cash flow ratio peaked in 1986 and then fell. The median ratio, however, remained constant, and the 90th percentile of the distribution increased from 1986 to 1988, a particularly striking development given the rapid growth in corporate earnings over this period. A similar pattern is observable when interest expense is measured relative to a three-year moving average of cash flow; unsurprisingly, the full sample ratio tends to fall by less while the ratio for higher segments of the distribution increases by more, because it gives less weight to high 1987 and 1988 income. The ratio of interest expense to current assets also displays the same pattern as that of the moving average ratio except at the 99 th percentile.

The numbers in table 3 take on additional significance when they are compared with our finding in our earlier paper that in 1986 debt-asset ratios and interest expense ratios were at levels previously seen only in the recessions of 1973-74 and 1981-82. ${ }^{8}$ The increase in interest burdens in the 1980s particularly stood out in that earlier paper, as did the fact that leverage increased more in highly levered than in more moderately levered firms.

What table 3 shows is that, contrary to expectations, debt-asset ratios and interest expense ratios have not fallen rapidly toward levels more normal for the past 20 years, but have fallen very slowly or, for the most indebted firms, even risen slightly. Even though earnings in 1987 and equity values in 1988 grew rapidly, for many firms interest expense and the value of debt grew even more quickly over the period.

7. Bernanke and Campbell (1988). A brief discussion of the 1988 methodology appears in the notes to table 3 .

8. Bernanke and Campbell (1988). The levels of the series in table 3 and in our earlier paper are not directly comparable, because the sample in this paper is different and some of the accounting conventions used on the COMPUSTAT tape have changed. (See the appendix for details.) However, we can splice growth rates up to 1986 (from the previous paper) to growth rates after 1986 (given here). 
Table 3. Distribution of Debt-Asset, Interest Expense, and Price-Earnings Ratios, COMPUSTAT Firms, 1986-88

\begin{tabular}{|c|c|c|c|c|c|c|}
\hline \multirow{2}{*}{$\begin{array}{c}\text { Financial } \\
\text { ratio and } \\
\text { year }\end{array}$} & \multirow{2}{*}{$\begin{array}{c}\text { Full } \\
\text { sample }\end{array}$} & \multicolumn{4}{|c|}{ Percentile } & \multirow{2}{*}{$\begin{array}{l}\text { Number of } \\
\text { firms in } \\
\text { full sample }\end{array}$} \\
\hline & & 50 & 90 & 95 & 99 & \\
\hline \multirow{2}{*}{\multicolumn{7}{|c|}{$\begin{array}{l}\text { Market value debt to assets } \\
\text { Method } \mathrm{A}^{\mathrm{b}}\end{array}$}} \\
\hline & & & & & & \\
\hline 1986 & 0.305 & 0.323 & 0.596 & 0.702 & 0.817 & 1,179 \\
\hline 1987 & 0.305 & 0.346 & 0.660 & 0.747 & 0.863 & 1,179 \\
\hline 1988 & 0.297 & 0.334 & 0.632 & 0.714 & 0.883 & 1,179 \\
\hline \multicolumn{7}{|l|}{ Method $B^{c}$} \\
\hline 1986 & 0.282 & 0.282 & 0.587 & 0.687 & 0.859 & 1,179 \\
\hline 1987 & 0.276 & 0.318 & 0.642 & 0.726 & 0.864 & 1,179 \\
\hline 1988 & 0.271 & 0.309 & 0.627 & 0.734 & 0.895 & 1,179 \\
\hline \multicolumn{7}{|c|}{ Interest expense to cash flow ${ }^{\mathrm{d}}$} \\
\hline 1986 & 0.188 & 0.219 & 1.713 & $\infty$ & $\infty$ & 1,177 \\
\hline 1987 & 0.174 & 0.219 & 1.247 & $\infty$ & $\infty$ & 1,177 \\
\hline 1988 & 0.168 & 0.219 & 1.859 & $\infty$ & $\infty$ & 1,177 \\
\hline \multicolumn{7}{|c|}{ Interest expense to moving-average cash flow ${ }^{\mathrm{d}}$} \\
\hline 1986 & 0.188 & 0.233 & 0.997 & 6.347 & $\infty$ & 1,137 \\
\hline 1987 & 0.185 & 0.244 & 1.168 & $\infty$ & $\infty$ & 1,137 \\
\hline 1988 & 0.187 & 0.243 & 1.481 & $\infty$ & $\infty$ & 1,137 \\
\hline \multicolumn{7}{|c|}{ Interest expense to current assets } \\
\hline 1986 & 0.087 & 0.052 & 0.247 & 0.355 & 0.819 & 1,174 \\
\hline 1987 & 0.081 & 0.053 & 0.250 & 0.369 & 0.712 & 1,174 \\
\hline 1988 & 0.084 & 0.059 & 0.259 & 0.374 & 0.623 & 1,174 \\
\hline \multicolumn{7}{|c|}{ Price to earnings } \\
\hline 1986 & 16.695 & 20.000 & $\ldots$ & $\ldots$ & . . & 1,175 \\
\hline 1987 & 12.664 & 14.584 & $\ldots$ & $\ldots$ & $\ldots$ & 1,175 \\
\hline 1988 & 11.459 & 14.020 & $\ldots$ & $\ldots$ & $\ldots$ & 1,175 \\
\hline
\end{tabular}

Source: Authors' calculations using the COMPUSTAT data base. Missing entries in the table correspond to negative earnings. Values of the ratios of interest expense to cash flow that are negative or greater than 100 are shown as $\infty$.

a. Full sample includes firms for which all data are available in 1986, 1987, and 1988 on a consistent basis.

b. Brainard-Shoven-Weiss approach, modified to reflect additional sample information (when available) about the maturity structures of firms' debt. Long-term debt is assumed to be issued at a 20 -year maturity. See Brainard, Shoven, and Weiss (1980) and Bernanke and Campbell (1988).

c. The market value of debt is measured by capitalizing reported interest payments, using the debt maturity structure and coupon rates implied in each year by Method A.

d. Ratio of interest expense to cash flow (operating income before depreciation, taxes, and interest expense are deducted). We use a three-year moving average for cash flow.

\section{Leverage and Macroeconomic Stability}

The most common reason for concern about increasing leverage is that it may have an adverse impact on macroeconomic stability. Our 
findings suggest that there is a basis for this concern. First, leverage has increased in durable goods industries, which are sensitive to the business cycle, as well as in more cyclically stable nondurable goods industries. Second, a recession like that of 1973-74 or 1981-82 would rapidly worsen financial conditions in many firms. Finally, although some argue that debt obligations have become easier to renegotiate when firms encounter financial difficulties, so that the corporate sector can safely increase its leverage, there is no evidence for such a change in the nature of corporate debt.

\section{Corporate Leverage by Industry}

It is sometimes claimed that the recent increases in leverage do not threaten the financial stability of the U.S. economy because they have taken place in noncyclical industries. This point is strongly argued by Stephen Roach and is also mentioned by Greenspan. ${ }^{9}$ Table 4 addresses this issue by showing market value debt-asset ratios broken down by industry and by industrial category. To give a longer historical perspective, numbers are reported for the periods 1970-75, 1976-81, and 198286 , as well as for 1986, 1987, and 1988. (See the appendix for details.) The table also gives the 1988 share of each industry in the market value of the sample as a whole. At the far right are the industry "earnings beta" (the coefficient from a regression of the growth rate of industry real earnings on the growth rate of real GNP) and "earnings sigma" (the standard deviation of the growth rate of industry real earnings). These are crude measures of the cyclical sensitivity or riskiness of each industry. The earnings beta and earnings sigma are generally strongly correlated, with the notable exception of the petroleum industry, whose earnings are highly variable but countercyclical over this period.

Until 1986, the cyclically stable nondurable manufacturing sector did

9. Roach (1988) and Greenspan (1989). Greenspan says, "Restructuring activity has been especially prevalent in the trade, services, and, more recently, the food and tobacco industries. For such businesses, a substantial increase in debt may raise the probability of bankruptcy by only a relatively small amount." On the other hand he also says that "roughly two-fifths of merger and acquisition activity, as well as LBO's, have involved companies in cyclically sensitive industries that are more likely to run into trouble in the event of a severe economic downturn." 


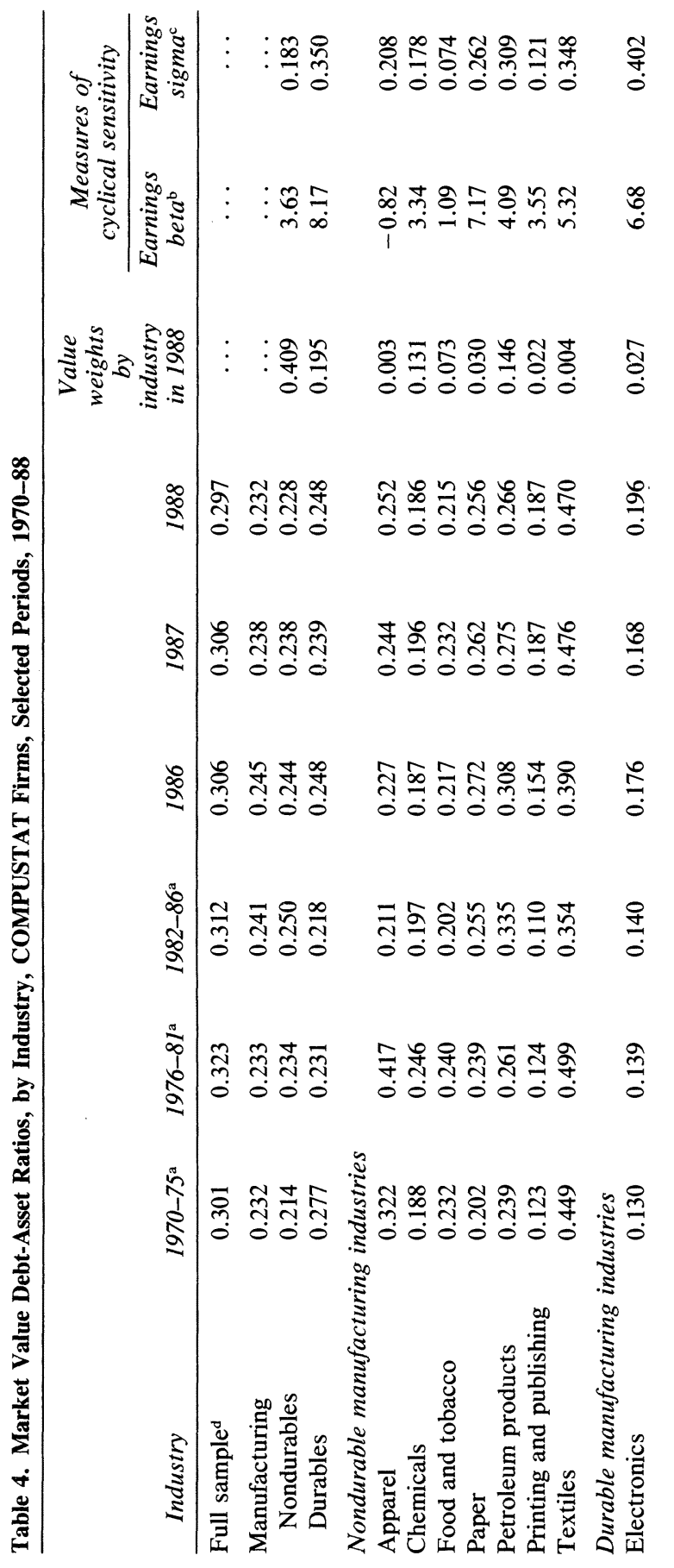




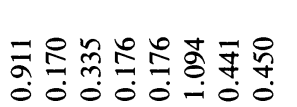

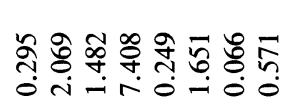

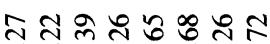

華

꿍워

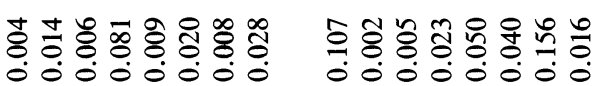

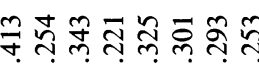

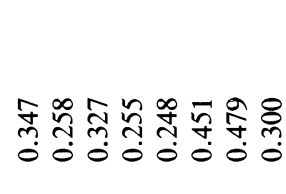

00000000

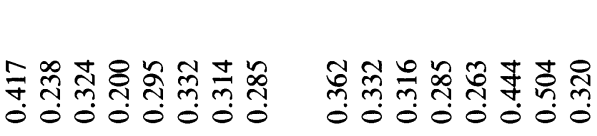

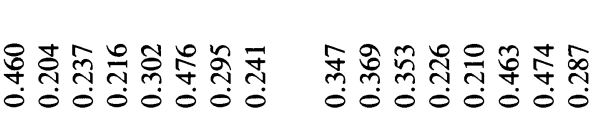

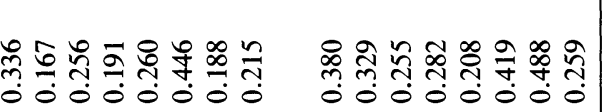

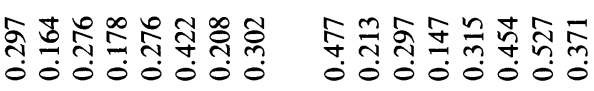

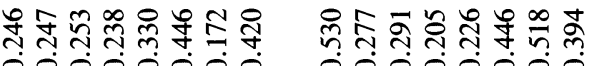

00000000

00000000

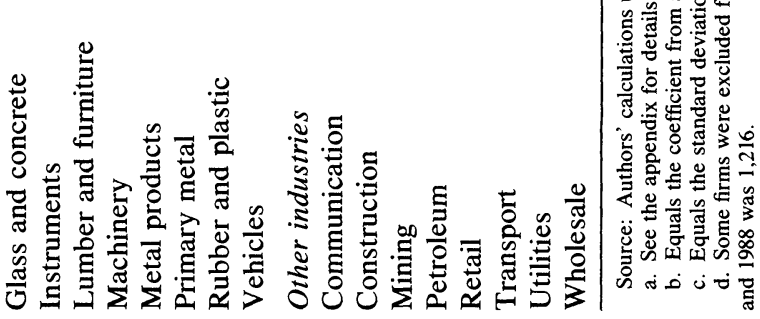


indeed increase its leverage faster than the durable manufacturing sector. The market value debt-asset ratio for nondurable manufacturing was 0.21 in $1970-75$, but it had risen to 0.25 by $1982-86$; the cyclically sensitive durable manufacturing sector, meanwhile, reduced its debtasset ratio from 0.28 to 0.22 over the same period. During 1986-88, however, these trends reversed. The debt-asset ratio for nondurables fell from 0.24 to 0.23 between $1982-86$ and 1988 , while the debt-asset ratio for durables rose from 0.22 to 0.25 . In 1988 the level of the debtasset ratio was higher for durable industries than for nondurable industries, just as it was in 1970-75 at the beginning of our sample period.

A breakdown of leverage by industry shows a wide diversity of experience. Some cyclical industries, like glass-concrete and transport, have high 1988 debt-asset ratios, while others, like vehicles and electronics, have much lower ratios. Figure 1 plots the 1988 debt-asset ratio of each industry against its earnings beta coefficient, showing that there is no clear relationship between the leverage of an industry and the riskiness of its earnings stream. ${ }^{10}$

Table 5 repeats the industry breakdown of table 4 for the ratio of interest expense to cash flow. Here again the nondurable sector shows greater increases in debt burdens up to 1986, but nondurable goods interest expense ratios fall slightly from 1986 to 1988. Interest expense ratios for the durable goods manufacturing sector have fluctuated but are higher than nondurable interest expense ratios in every period.

Figure 2 plots the ratio of 1988 interest expense to cash flow of each industry against its earnings beta. The figure gives a weak visual impression of a negative relationship between interest expense and earnings beta, but this is caused almost entirely by the petroleum industry, which has a negative earnings beta and a 1988 interest expense ratio of $0.45 .{ }^{11}$ Overall there is no clear tendency for cyclical industries to have either lower or higher leverage than noncyclical industries.

10. The figures look broadly similar if the $1986-88$ average debt-asset ratio, or the change in the debt-asset ratio over 1986-88, or the change from 1971-80 to 1986-88, is plotted on the vertical axis. A figure with the earnings sigma (the standard deviation of earnings growth) on the horizontal axis also shows no clear relation between industry leverage and earnings risk.

11. A figure with the earnings sigma on the horizontal axis gives a weak impression of a positive relationship between risk and leverage, but again this is largely due to the petroleum industry outlier. 
Figure 1. 1988 Market Value Debt-Asset Ratio and Cyclical Sensitivity of Industry Earnings

Debt-asset ratio

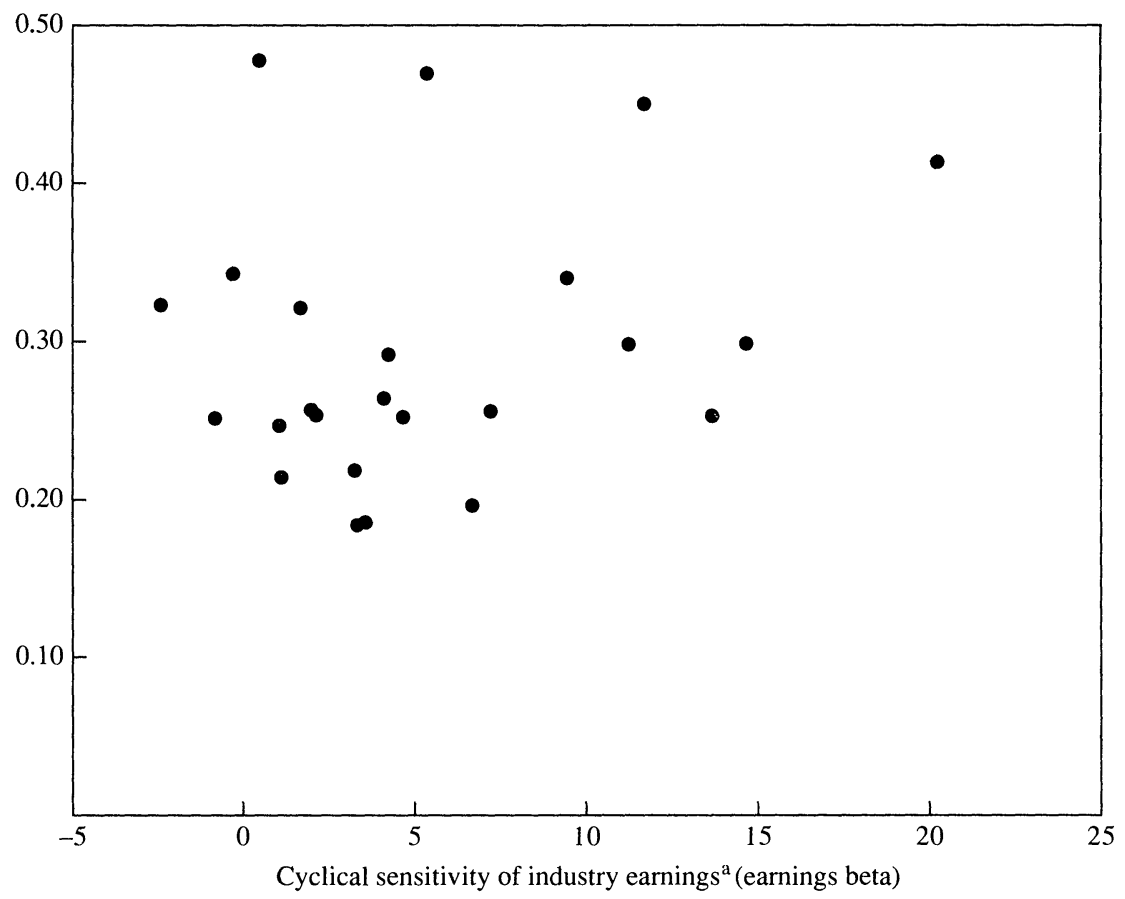

Source: Authors' calculations using COMPUSTAT data base and reported in table 4 .

a. Cyclical sensitivity measure is equal to earnings beta from table 4 , the coefficient from a regression of the growth rate of industry real earnings on the growth rate of real GNP.

\section{The Impact of a Recession}

In view of the 1986-88 increase in U.S. corporate leverage, particularly in more highly levered firms and in cyclically sensitive industries, it should not be surprising that many U.S. corporations appear vulnerable to financial distress in the event of a major recession.

In our earlier paper we simulated the effects of the 1973-74 recession and the 1981-82 recession on corporations with a 1986 capital structure. ${ }^{12}$

12. During the 1973-74 recession the value of the stock market fell sharply. Under these simulation conditions debt-asset ratios would be expected to worsen as the market value of firms declines. During the 1981-82 recession the stock market fell less, but interest rates were very high. Under these simulation conditions interest expense burdens would be expected to rise. 


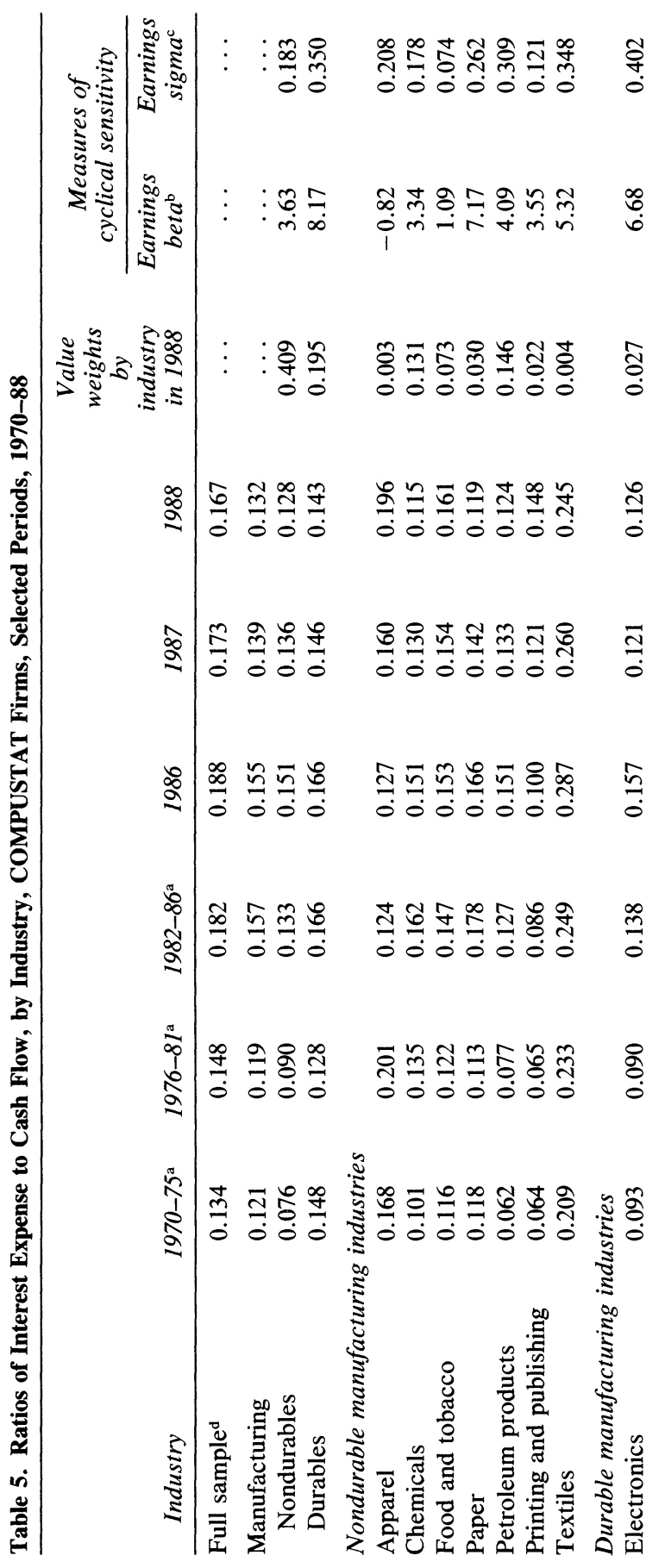




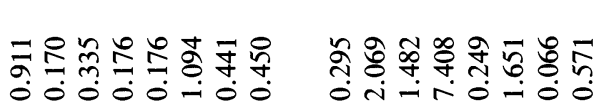

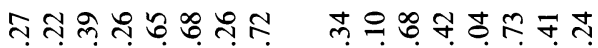

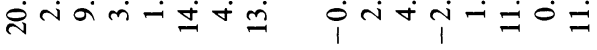

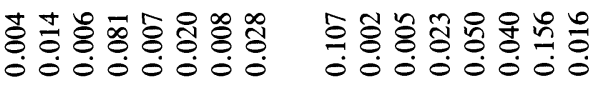
గ్య

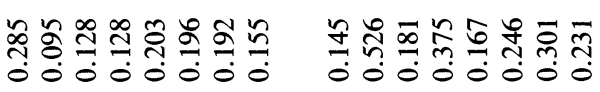

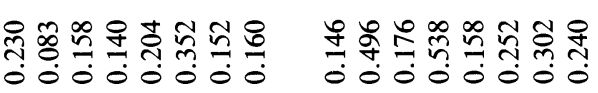

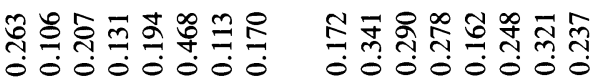

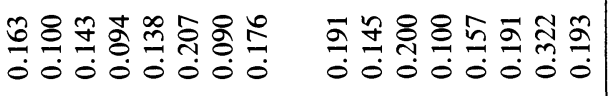

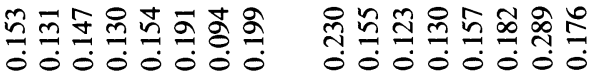

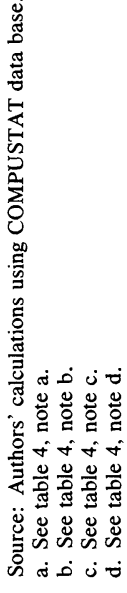


Figure 2. 1988 Interest Expense-Cash Flow Ratio and Cyclical Sensitivity of Industry Earnings

Interest expense - cash flow ratio

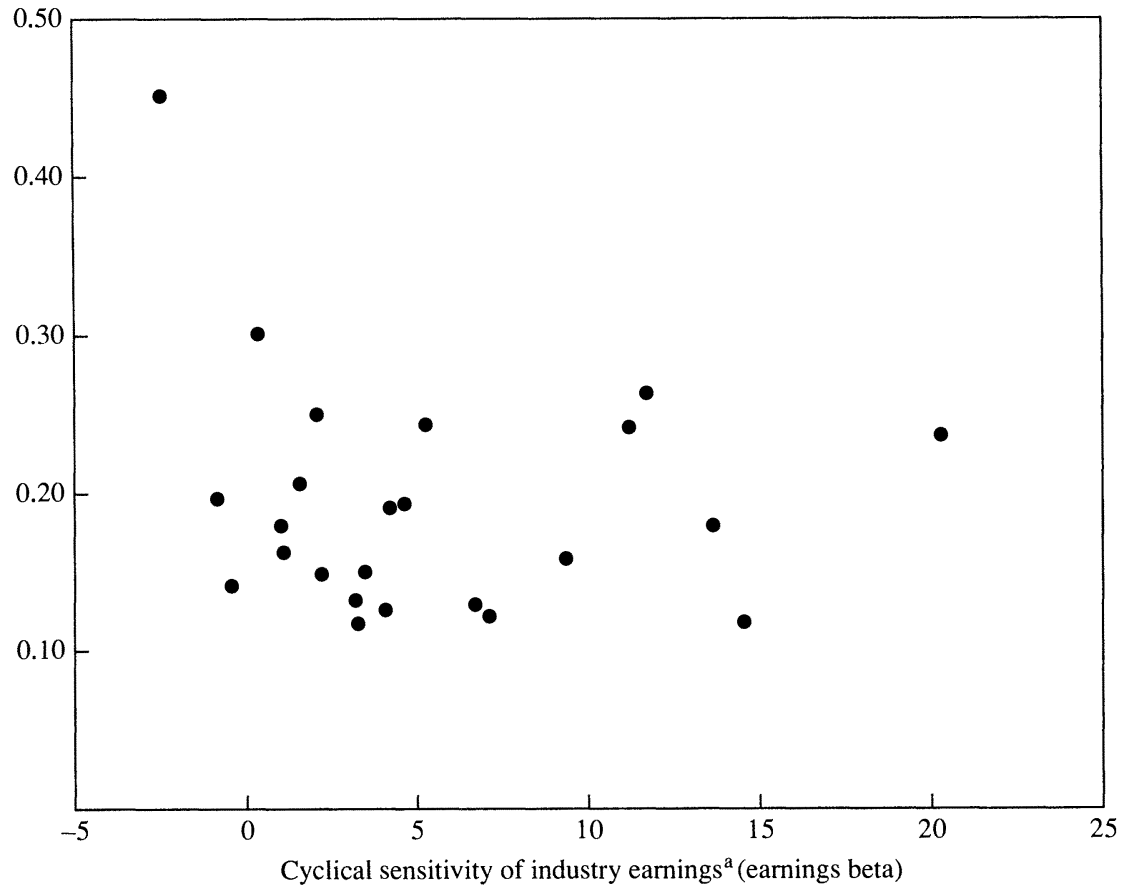

Source: Authors' calculations using COMPUSTAT data base and reported in table 5 .

a. Measure of cyclical sensitivity of industry earnings equal to earnings beta from table 5 , the coefficient from a regression of the growth rate of industry real earnings on the growth rate of real GNP.

About 20 percent of the firms in our sample encountered solvency problems by the second year of the 1973-74 simulation, and a similar fraction of the firms encountered liquidity problems by the second year of the 1981-82 simulation. ${ }^{13}$ In table 6 (left-hand side), we obtain qualitatively similar results for our sample of 1988 corporations. The 1973-74 simulation is particularly dramatic: the full sample debt-asset ratio for firms that reported data in both 1973-74 and 1988 rises from 0.30 in 1988 to 0.45 in the first year of the simulation, and to 0.70 in the

13. Bernanke and Campbell (1988, p. 120). By a "solvency problem," we mean a simulated debt-asset ratio greater than unity; by a "liquidity problem," we mean a simulated interest expense to cash flow ratio greater than one or less than zero (negative ratios arise when cash flow becomes negative). 
Table 6. Simulations of the 1973-74 and 1981-82 Recessions on Corporate Financial Structure of 1988, COMPUSTAT Firms

\begin{tabular}{|c|c|c|c|c|c|c|c|c|}
\hline \multirow[b]{3}{*}{ Year } & \multicolumn{4}{|c|}{ Variable interest rates } & \multicolumn{4}{|c|}{ Fixed interest rates } \\
\hline & \multirow{2}{*}{$\begin{array}{c}\text { Full } \\
\text { sample }^{\mathrm{a}}\end{array}$} & \multicolumn{3}{|c|}{ Percentile } & \multirow{2}{*}{$\begin{array}{c}\text { Full } \\
\text { sample }^{\mathrm{a}}\end{array}$} & \multicolumn{3}{|c|}{ Percentile } \\
\hline & & 50 & 75 & 90 & & 50 & 75 & 90 \\
\hline \multicolumn{9}{|l|}{ 1973-74 recession } \\
\hline \multicolumn{9}{|l|}{ Debt-asset ratio } \\
\hline 1988 & 0.302 & 0.318 & 0.484 & 0.640 & n.a. & n.a. & n.a. & n.a. \\
\hline Recession year 1 & 0.447 & 0.457 & 0.864 & $\infty$ & n.a. & n.a. & n.a. & n.a. \\
\hline Recession year 2 & 0.695 & 0.621 & $\infty$ & $\infty$ & n.a. & n.a. & n.a. & n.a. \\
\hline \multicolumn{9}{|c|}{ Interest expense-cash flow ratio } \\
\hline 1988 & 0.182 & 0.212 & 0.358 & 1.034 & 0.182 & 0.212 & 0.358 & 1.034 \\
\hline Recession year 1 & 0.153 & 0.216 & 0.404 & 1.092 & 0.152 & 0.215 & 0.403 & 1.089 \\
\hline Recession year 2 & 0.142 & 0.234 & 0.447 & 1.323 & 0.137 & 0.222 & 0.427 & 1.242 \\
\hline \multicolumn{9}{|l|}{ 1981-82 recession } \\
\hline \multicolumn{9}{|l|}{ Debt-asset ratio } \\
\hline 1988 & 0.291 & 0.330 & 0.485 & 0.633 & n.a. & n.a. & n.a. & n.a. \\
\hline Recession year 1 & 0.310 & 0.337 & 0.500 & 0.660 & n.a. & n.a. & n.a. & n.a. \\
\hline Recession year 2 & 0.291 & 0.311 & 0.478 & 0.710 & n.a. & n.a. & n.a. & n.a. \\
\hline \multicolumn{9}{|c|}{ Interest expense-cash flow ratio } \\
\hline 1988 & 0.172 & 0.216 & 0.383 & 1.295 & 0.172 & 0.216 & 0.383 & 1.295 \\
\hline Recession year 1 & 0.202 & 0.243 & 0.467 & 5.383 & 0.189 & 0.229 & 0.436 & 4.397 \\
\hline Recession year 2 & 0.225 & 0.275 & 0.718 & $\infty$ & 0.206 & 0.255 & 0.670 & $\infty$ \\
\hline
\end{tabular}

Source: Authors' calculations using COMPUSTAT data base. For complete description of the simulation method, see Bernanke and Campbell (1988). Values of debt-asset ratios greater than unity are shown as $\infty$. Values of the ratios of interest expense to cash flow that are negative or greater than 100 are shown as $\infty$.

n.a. Not available.

a. The sample for the 1973-74 recession simulation is a set of 617 firms that had complete data available during 1972-74 and 1988; the sample for the 1981-82 simulation is a set of 875 firms that had complete data during 1980-82 and 1988 .

second year of the simulation. By the second year of the simulation, just over 25 percent of the firms in the sample have become insolvent in the sense that their simulated debt-asset ratios are greater than unity. ${ }^{14}$ In other words, these firms have equity cushions in 1988 that are less than the decline in their market value during the 1973-74 recession. The 198182 simulation has flat debt-asset ratios but large increases in interest expense ratios, so that just over 20 percent of the firms in the sample have liquidity problems in the second year of the simulation.

14. The very high fraction of predicted insolvencies no doubt reflects to some degree the crudeness of the simulation procedure. Our preferred interpretation of these numbers is as an indicator of potential vulnerability to financial distress, not as a literal prediction. 


\section{Interest Rate Hedging}

One objection to these simulations is that they assume that firms with short-term debt outstanding are vulnerable to increases in refinancing costs if interest rates rise. In recent years, however, corporations have increasingly used interest rate swaps (and related techniques such as interest rate caps and swap options) to hedge interest rate risk. A firm that has swapped floating-rate for fixed-rate debt continues to have floating-rate liabilities reported on its balance sheet and on the COMPUSTAT tape, but it has no exposure to general increases in the level of interest rates. ${ }^{15}$

The interest rate swap market is quite large relative to the outstanding debt of our sample of corporations. In 1988 U.S. dollar interest rate swaps with a principal value of $\$ 484$ billion were carried out by members of the International Swap Dealers Association (the trade association for the financial institutions that organize these transactions). ${ }^{16}$ The total book debt outstanding for our sample of firms in 1988 is $\$ 675$ billion (table 2).

It should not be inferred from the volume of swaps, however, that nonfinancial corporations have completely hedged their interest rate risks. First, probably less than half the total swap volume involved nonfinancial corporations; the remainder was attributable to financial institutions or government agencies. Second, the maturities involved are generally quite short, with about 20 percent of the 1988 swaps having a one-year maturity and 30 percent having a two- to three-year maturity. Short maturities limit the effectiveness of swaps in hedging the risk of persistent changes in interest rates. And, third, to the extent that swaps

15. The firm is not in the same position as if it had issued fixed-rate debt, however, because it is still exposed to an increase in its own borrowing cost relative to the floating rate used in the swap agreement. Such an increase could occur either because the firm's credit rating falls, or because the yield spread between bonds of the firm's rating and highquality bonds increases. Also fixed-rate debt can often be prepaid or called at or close to par, while swap agreements can only be terminated by marking them to market. See Arak, Estrella, Goodman, and Silver (1988); Bicksler and Chen (1986); Price and Henderson (1988); and Smith, Smithson, and Wakeman (1988) for detailed accounts of the interest rate swap market.

16. We are grateful to the ISDA for supplying this information. The $\$ 484$ billion figure excludes swaps carried out between ISDA members. 
occur between nonfinancial corporations, interest rate risk has not been removed from corporate balance sheets, only redistributed.

Nevertheless, the difficulty for our simulation methodology is that the most highly levered firms, which encounter the most serious problems in our simulations, may be the ones that make the most effective use of interest rate swaps. If this is the case, then even the small part of the swap market that is long-term and involves nonfinancial corporations might have a big effect on our results.

As a crude way to test for this possibility, the right-hand side of table 6 repeats our simulations of interest expense ratios fixing interest rates at the levels prevailing in the base year of the simulation. This is equivalent to assuming that firms are fully hedged and can roll over all their debts at fixed interest rates. The results are very close to those in the simulations with variable interest rates, indicating that liquidity problems occur primarily because earnings and the market value of assets drop in a recession, not because short-term interest rates increase.

\section{A Change in the Nature of Debt}

A possible counterargument to our concerns about leverage is that increased corporate debt poses little threat to financial stability because of a change in the nature of debt during the 1980s. In particular, it has been argued that fixed interest obligations have become less costly to renegotiate-more like equity in this respect-so that the potential bankruptcy costs associated with any given amount of leverage are reduced. ${ }^{17}$

It is certainly possible that such a change in the nature of debt has occurred, but the fact is that we have very little hard evidence. ${ }^{18}$ As a practical matter, explicit attempts to make debt more like equity are

17. See Gertler and Hubbard (1989) for an insightful discussion of the issues. Bernanke and Campbell (1990) also touch on these points. Giammarino (1989) presents a theoretical model that explains why costless renegotiation is not always preferred to the costly use of the bankruptcy law. Gilson, John, and Lang (1989) discuss some recent cases of reorganization of firms in financial distress.

18. One fact that ought to be easily ascertainable is how many firms have gone into bankruptcy court. Even this is muddled, unfortunately, by a change in Dun and Bradstreet's business failure coverage in 1984 . However, we can say that the business failure rate roughly quadrupled between 1979 and 1983 and has remained relatively stable since 1984; see the Economic Report of the President, February 1990, table C-94, p. 402. 
hampered by the scrutiny of the Internal Revenue Service; for example, it is not possible to link principal obligations to macroeconomic conditions (which from a theoretical point of view would be highly desirable) without losing tax deductibility. ${ }^{19}$ Closer holding of a firm's debt obligations should tend to lower renegotiation costs, but there is not much evidence of a U.S. trend toward such Japanese-style arrangements. It is known that junk bonds, for example, are more widely held than more traditional forms of corporate debt such as private placements and bank debt. And because junk bonds, especially recent issues, have elaborate covenants that restrict further borrowing by corporations, distressed corporations find it more difficult to continue operating while renegotiation takes place. ${ }^{20}$

\section{Leverage and Efficiency}

Is it possible that increased corporate leverage can offer social benefits that offset the increased instability it introduces into the U.S. economy? Proponents of leverage argue that corporate efficiency is greatly enhanced by the pressure of debt obligations that prevent managers from wasting "free cash flow." 21

Empirical work on this question has focused almost exclusively on leveraged buyouts. Frank Lichtenberg and Donald Siegel, for example, report that total factor productivity (TFP) increases, while administrative overhead costs decrease, after firms undergo LBOs. ${ }^{22}$ Here we look more broadly at leverage in manufacturing industries and search for links between the growth of leverage and productivity in the 1980s.

Table 7 summarizes an alternative source of evidence on leverage by industry. The data come from the Quarterly Financial Report of the Bureau of the Census. The table gives debt-asset ratios at book value (no market value data are available from the QFR), and in this respect

19. Gertler and Hubbard (1989).

20. See Baker and Wruck (1990) for a description of the bond convenants involved in one recent $\mathrm{LBO}$.

21. Jensen (1989). We note an apparent contradiction between this argument, that fear of bankruptcy is an important device for controlling managerial behavior, and the claim, just discussed, that ease of renegotiation makes bankruptcy inconsequential.

22. Lichtenberg and Siegel (1989a, 1989b). 
Table 7. Book Value Debt-Asset Ratios and Total Factor Productivity, Sample of QFR Manufacturing Industries, Selected Years, 1977-88

\begin{tabular}{|c|c|c|c|c|c|c|c|}
\hline \multirow[b]{2}{*}{ Industry } & \multicolumn{5}{|c|}{ Book value debt-asset ratio ${ }^{\mathrm{a}}$} & \multicolumn{2}{|c|}{$\begin{array}{c}1986 \mathrm{TFP} \\
\text { (index, } 1981=100 \text { ) }\end{array}$} \\
\hline & 1977 & 1981 & 1984 & 1986 & $1988^{\mathrm{b}}$ & Actual & Adjusted ${ }^{\mathrm{c}}$ \\
\hline Manufacturing & 0.216 & 0.222 & 0.225 & 0.259 & 0.276 & 110 & 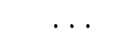 \\
\hline \multicolumn{8}{|c|}{ Nondurable manufacturing } \\
\hline Chemicals & 0.244 & 0.256 & 0.222 & 0.267 & 0.278 & 113 & 103 \\
\hline Food & 0.263 & 0.264 & 0.311 & 0.347 & 0.361 & 104 & 101 \\
\hline Paper & 0.205 & 0.261 & 0.284 & 0.312 & 0.286 & 113 & 103 \\
\hline Petroleum products & 0.168 & 0.174 & 0.229 & 0.269 & 0.269 & 104 & 105 \\
\hline $\begin{array}{l}\text { Printing and } \\
\text { publishing }\end{array}$ & 0.189 & 0.236 & 0.234 & 0.299 & 0.311 & 97 & 94 \\
\hline Textiles & 0.262 & 0.252 & 0.270 & 0.304 & 0.388 & 108 & 99 \\
\hline Tobacco $^{d}$ & 0.311 & 0.272 & 0.220 & 0.366 & $\ldots$ & 80 & 89 \\
\hline \multicolumn{8}{|l|}{ Durable manufacturing } \\
\hline Electronics & 0.171 & 0.175 & 0.166 & 0.196 & 0.211 & 113 & 96 \\
\hline Glass and concrete & 0.244 & 0.273 & 0.271 & 0.342 & 0.373 & 107 & 105 \\
\hline Instruments & 0.161 & 0.138 & 0.155 & 0.194 & 0.297 & 104 & 96 \\
\hline Machinery & 0.198 & 0.235 & 0.201 & 0.226 & 0.245 & 130 & 113 \\
\hline Metal products & 0.219 & 0.220 & 0.256 & 0.284 & 0.301 & 105 & 101 \\
\hline Primary metal & 0.284 & 0.272 & 0.316 & 0.321 & 0.307 & 102 & 94 \\
\hline Rubber and plastic & 0.261 & 0.262 & 0.248 & 0.303 & 0.361 & 109 & 101 \\
\hline Vehicles & 0.146 & 0.172 & 0.116 & 0.162 & 0.173 & 109 & 99 \\
\hline
\end{tabular}

Source: Data for debt-asset ratios from Bureau of the Census, Quarterly Financial Report for Manufacturing, Mining, and Trade Corporations (Department of Commerce, various years). Total factor productivity data from Bureau of Labor Statistics, Department of Labor.

a. Ratio is equal to book value of debt (short-term debt plus long-term debt) as a percentage of total assets.

b. Debt-asset ratio data for $\mathbf{1 9 8 8}$ are from the second quarter. All other data are fourth quarter.

c. Adjusted TFP obtained by regressing each industry's TFP growth on a constant, a dummy equal to one for 1973 and later years (to allow for the "productivity slowdown"), the lagged industry TFP growth rate, and the growth rate of total manufacturing TFP.

d. After 1985, because of mergers and acquisitions, the QFR stopped reporting tobacco manufactures (SIC code 21) balance sheet data. The 1986 number in the table is actually from 1985:4.

the numbers are less satisfactory than those reported in tables 4 and 5 . On the other hand, the QFR data are much more comprehensive (see the appendix for a description of these data).

The debt-asset ratios in table 7 show larger increases over 1986-88 than do the ratios reported in table 4 . This discrepancy reflects both the difference between market value and book value ratios and the broader coverage of the QFR data. ${ }^{23}$ It is reassuring, however, that the relative changes in leverage of different industries are quite similar in tables 4

23. Recall that the aggregate Flow of Funds data, which use market value of equity, also show stronger increases than our COMPUSTAT sample. 
and 7. The changes in debt-asset ratios from 1986 to 1988, for example, have a correlation of 0.6 across the two tables.

Table 7 also reports two measures of total factor productivity growth during 1981-86-“"actual TFP" and "adjusted TFP." Actual TFP is a TFP index number from the Bureau of Labor Statistics, normalized so that each industry had total factor productivity of 100 in 1981. Adjusted TFP is the ratio of actual to predicted TFP growth and therefore measures the unexpected part of TFP growth. If leverage encouraged productivity growth, it should show up in the relation of leverage, or change in leverage, to one of these TFP growth measures.

To obtain predicted TFP, we first regressed each industry's TFP growth on a constant, a dummy equal to one for 1973 and later years (to allow for the much-discussed "productivity slowdown"), the lagged industry TFP growth rate, and the growth rate of total manufacturing TFP. The sample period for these regressions was 1949-81. We then used the estimated equations to forecast industry TFP in 1986. The simulations used actual manufacturing TFP, but simulated lagged industry TFP, so they were dynamic simulations with respect to industry TFP.

Table 7 shows no strong relationship between leverage and TFP growth across industries. Regressions of actual and adjusted TFP growth on the 1981-86 changes in leverage (absolute or as a percentage of 1981 leverage) yield small and insignificant coefficients, which are negative in three out of four cases. ${ }^{24}$

One should not draw excessively strong conclusions from the numbers in table 7. It is possible that there is a problem of reverse causality; it may be that leverage actually does increase productivity growth, but that the industries that increased leverage fastest in 1981-86 were those that were experiencing the most severe productivity growth problems. ${ }^{25}$ What table 7 does show is that the efficiency benefits often attributed to corporate leverage have as yet left no mark in industry-level data.

24. An alternative measure of efficiency might be accounting return to capital (beforetax earnings plus interest expense, divided by the replacement value of the capital stock). We computed return to capital numbers by industry, using our COMPUSTAT data set. Again there is no clear relationship between leverage and this measure of efficiency.

25. See Blair and Litan (1989) for evidence that industries with a low return to capital in the 1970 s have tended to increase leverage fastest in the 1980 s. 


\section{Implications for Policy}

Conventional measures of leverage show little improvement in corporate debt burdens between 1986 and 1988, despite continuing economic expansion and a strong stock market. There is little or no evidence that leverage is concentrated in particularly stable industries or in industries displaying improved productivity growth. The potential risks of corporate debt for macroeconomic stability should be taken seriously, while the potential efficiency benefits should be regarded as unproven.

Should policy intervene to discourage high levels of corporate debt? In the abstract, the case for overruling the free market's capital structure decisions is not difficult to make. Firms' leverage decisions create externalities at both the microeconomic and macroeconomic levels. At the microeconomic level, the risk of financial distress is borne not only by the firm's managers and owners, but by its workers, suppliers, and customers, among others. Managers have little incentive to take the costs imposed on third parties into account when deciding how much debt to issue. At the macroeconomic level, both traditional Keynesian models and more recent theories of aggregate demand externalities and multiple equilibria ascribe great importance to how firms respond to changes in current economic activity (that is, firms' decisions create an externality). According to these theories, the more sensitive firms' spending plans are to their current cash flow, the more unstable the macroeconomy will be; in Keynesian terms, high sensitivity implies a high multiplier. Theory and empiricism both suggest that the pressure of debt service will cause highly leveraged firms to cut back investment (and, possibly, production and employment) more severely than will low-leverage firms when current cash flow falls; thus high leverage may make the macroeconomy less stable. Again, this possibility will not be taken into account in private capital structure decisions.

Despite the prima facie case for policy, however, we do not advocate any extreme intervention in the determination of capital structure. Precisely because the profession's understanding of how capital structure affects the economy is so rudimentary, any policy changes should be slow and incremental. One attractive strategy would be to reduce artificial incentives for high leverage, including the tax advantage given 
to debt over equity and the implicit subsidization of high leverage through the deposit insurance system.

Another potential role for policy, which would directly address the concerns of some advocates of high leverage, is to improve our system of corporate governance. Possibilities here include eliminating legal barriers to paying managers profit-based compensation and strengthening the powers and incentives of directors to monitor managerial performance. ${ }^{26}$

\section{APPENDIX}

\section{Description of the Data}

IN PREPARING this paper we tried to repeat as closely as possible the procedures used in our earlier paper. ${ }^{27}$ We began by comparing the 1989 COMPUSTAT tape, which gives data through 1988, with the 1987 COMPUSTAT tape used in our earlier paper.

Our earlier paper had a sample of 1,386 firms in 1986. The 1989 COMPUSTAT tape had complete 1988 data on 239 new firms that were not in our earlier sample, but it lacked complete data on 282 firms that were in the earlier sample. Of these, 128 were on the 1989 COMPUSTAT tape but had to be omitted because they provided incomplete data, while 154 were missing from the 1989 tape altogether. Of these 154 firms, only 13 disappeared from the tape because of LBOs, while 10 went private. One hundred and eighteen firms disappeared because of mergers or acquisitions, and 13 firms disappeared for miscellaneous reasons (including 2 bankruptcies, 2 liquidations, and 3 delistings). Many acquired firms remain in our sample indirectly if the acquiring firm provides complete data. This analysis suggests to us that the omission of LBOs from our sample will not cause any serious bias in our results.

The 1989 COMPUSTAT tape has one very important change from earlier COMPUSTAT tapes. In 1988 the Financial Accounting Standards Board instituted a new rule, FASB94, which requires all companies to

26. Shleifer and Vishny (1988).

27. Bernanke and Campbell (1988). 
consolidate the balance sheets of their wholly owned subsidiaries. This change had the greatest impact on firms with large finance companies, such as the big three auto manufacturers. The 1989 COMPUSTAT tape gives 1988 data stated under the new rule for all firms, but the historical data have been restated on a consistent basis only for some firms. This could bias our calculations of trends in corporate leverage, because for some firms the debt of subsidiaries is now measured although it was not before.

To correct this problem we first divided the original sample of 1,343 $(1,386+239-282)$ companies into two groups: those that reported restated data for 1986 and 1987 (840 firms) and those that did not (503 firms).

For the group with restated data we first deemed suspect those with outstanding debt greater than $\$ 100$ million in either 1987 or 1988 . We then checked each of these firms against data from Moody's Industrial Manual, deleting those with major wholly owned subsidiaries whose restated data are not significantly different from the old data. (Presumably these firms claim to have restated their data when in fact they have not.) This process led to the deletion of 11 firms.

For the group without restated data we first decided to retain any firm whose reported nominal asset growth was less than 6 percent and whose reported debt growth was zero or less. Of those remaining (344), we once again deemed suspect those with outstanding debt greater than $\$ 100$ million in either 1987 or 1988 . We checked Moody's Industrial Manual and deleted all such firms with major wholly owned subsidiaries. This process led to the deletion of 79 firms from the original sample.

Of the 1,253 firms remaining, some reported data only for 1987 and 1988 , and not for 1986 . We excluded these firms from the sample used in tables 1,2 , and 3 , leaving a sample size of 1,179 . However, we included these firms in the sample used in tables 4 and 5. Some extra firms were excluded from the sample in these tables because they did not fit into any of our major industrial categories.

To create older data for tables 4 and 5, we combined restated data for the years 1986, 1987, and 1988 with nonrestated data for years up to and including 1986. We used the nonrestated data to create growth rates of debt-asset ratios and interest expense-current income ratios up to 1986 , and then combined these with the restated 1986 levels to get implied 
restated levels for earlier years. The sample used in tables 4 and 5 is always the largest available in each year.

The data on leverage in table 7 are from the U.S. Department of Commerce, Bureau of the Census, Quarterly Financial Report for Manufacturing, Mining, and Trade Corporations. The numbers in the table are short-term debt including installments on long-term debt plus long-term debt, as a percentage of total assets. Data are fourth-quarter, except for 1988, which are second-quarter (the most recent available). From mid-1977 until the end of 1986, the QFR numbers measure all firms in the industry; before and after those dates, firms with assets less than $\$ 250,000$ are excluded. The 1988 leverage column is thus not exactly comparable with the other columns in the table. However, the QFR gives 1976 and 1986 numbers both including and excluding the small firms, and the differences are extremely small.

The total factor productivity indexes in table 7 are based on numbers available from the U.S. Department of Labor, Bureau of Labor Statistics. BLS data are available for the 20 two-digit SIC manufacturing industries (SIC 20-39), and for aggregate manufacturing. Of the 20 manufacturing industries, 15 are also covered by the QFR daia, and these are the industries reported in the table. 


\section{Comments and Discussion}

Mark Warshawsky: In this paper, Ben Bernanke, John Campbell, and Toni Whited have updated and expanded upon Bernanke and Campbell's earlier Brookings paper examining the financial stability of the U.S. nonfinancial corporate sector. Using data from the 1986, 1987, and 1988 annual reports of large corporations recorded on the COMPUSTAT files, they have again constructed statistics describing the distributions of some indicators of financial stress, namely, the ratios of debt to assets, at market value, and of interest expense to operating income. The authors also have again run simulations of the impact that recessions like those of 1973-74 and 1981-82 would have on the solvency and liquidity of nonfinancial corporations, this time given 1988 balance sheets. While they find that median and full sample statistics of indicators of financial stress have actually improved slightly over the period, statistics describing the tails of the distributions-the 90th percentile and the simulations-show a further deterioration in conditions.

In addition to updating their earlier analysis to include data for 1987 and 1988-years that exhibited a continued brisk, even accelerated, pace of restructuring activity, and volatile share prices and earnings-Bernanke, Campbell, and Whited examined the evidence for three arguments advanced by those supporting, or at least unperturbed by, the increased leverage of many corporations. The first argument maintains that the increased leverage has been concentrated in noncyclical industries and hence poses little or no risk to financial stability or to overall economic activity. The second argument asserts that interest rate hedging implemented by swaps, caps, and options effectively reduces the vulnerability of some corporations with high leverage to increases in interest rates. The third argument states that although increases in leverage may pose difficulties in certain economic scenarios, the overall improvements in 
productivity resulting from restructuring activity are worth the riskreward trade-off. The authors produce evidence contrary to all three arguments.

I think this paper is a worthy supplement to their earlier carefully crafted and highly original paper. I do, however, have some problems with some points in both papers and, in particular, I am not persuaded by the evidence on the productivity-leverage question. In my comments, I will, in part, draw upon my own paper extending and expanding Bernanke and Campbell's earlier analysis. ${ }^{1}$

While the authors correctly focus on data from the COMPUSTAT files giving information about the financial situation of a sample of large public corporations, it is nevertheless interesting, for purposes of comparison, to examine aggregate statistics from the Flow of Funds Accounts that attempt to include information about all, large and small, public and private, nonfinancial corporations. As shown in the solid line of figure 1 , the ratio of debt liabilities to total assets at historical cost has risen rapidly since 1982, and in 1988 was at a level close to the high reached in 1973. The picture changes considerably, however, when market values are substituted for historical cost. As shown in the dashed line of the figure, the debt-to-asset ratio at market value has actually declined since 1982, although the level recorded in 1989 still exceeds the lower levels of the late $1960 \mathrm{~s}$. Apparently the strong equity market has increased asset values more than restructuring activity has increased debt outstanding. It is interesting to note that the level of the debt-toasset ratio at market value in 1988 shown in the figure-0.42-exceeds the full sample ratio reported by the authors in their table $3-0.297$ or 0.271 . Based on evidence presented in my own paper, this difference can be attributed, in small part, to the higher ratios of corporations not included in the authors' sample-small firms, as well as companies that disappeared over the years owing to mergers, bankruptcies, and so on. A more significant explanation of the difference, however, lies in the different methods used to convert the par value of long-term debt to market value. The authors employ a rather elaborate algorithm using company-specific information for the conversion, while I use an aggregate approach - the ratio of the market to par value of corporate bonds listed on the New York Stock Exchange-in my calculation. As I show

1. Warshawsky (1990). 
Figure 1. Ratio of Debt Liabilities to Total Assets, Nonfinancial Corporate Business, 1969-89

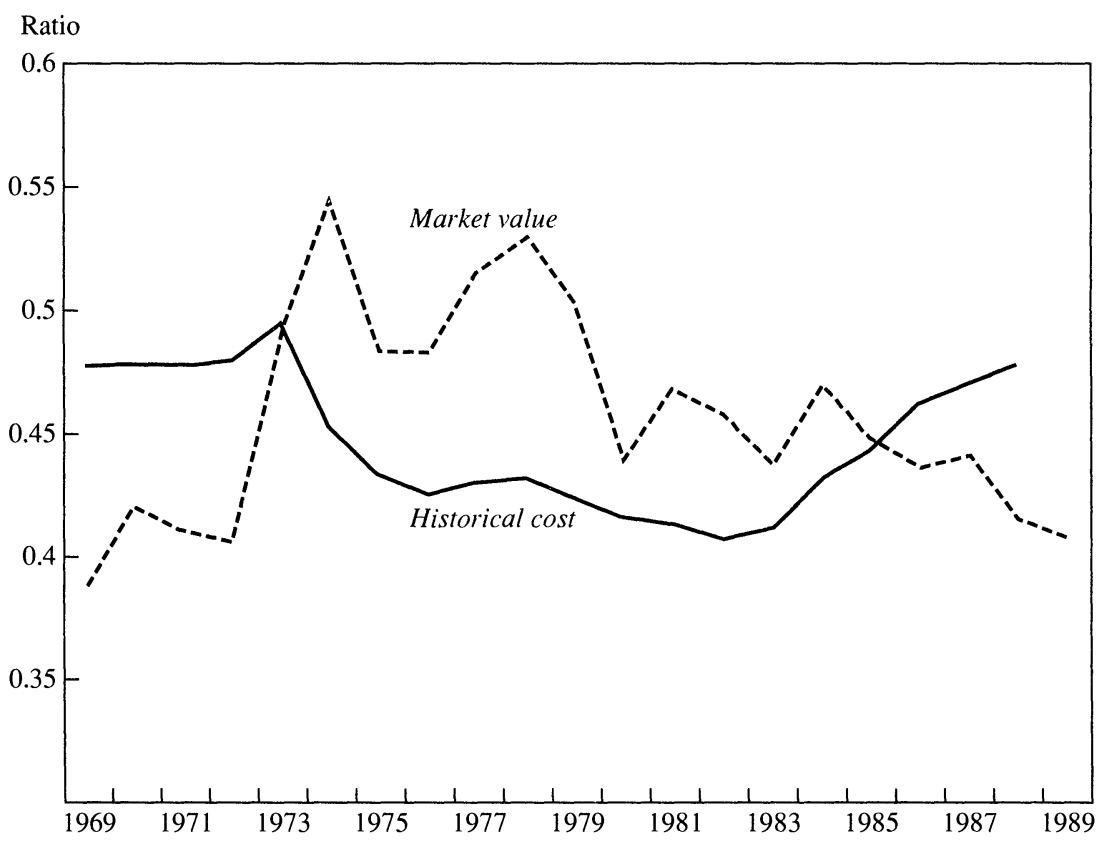

Source: Flow of Funds Accounts. For the market value of debt, bonds and other long-term securities are adjusted by the ratio of market to par value of corporate bonds listed on the NYSE. The market value of assets equals the market values of debt and equity.

in my paper, at the level of prices of debt obligations of specific companies, the aggregate approach is often more accurate than the algorithm used by the authors.

While the aggregate and full sample ratios of debt to assets, at market value, indicate an improving situation, there are many reasons why this evidence is incomplete. In the first instance, the market value of assets, based largely on the market value of equity, may not reflect the fundamental value of firms. In the second instance, it is often more instructive to know what is occurring among outliers than among average corporations. Most important, however, the market value of equity is determined by the views of investors as to what is most likely to happen in the future. The stock market, for purposes of valuation, is interested in the probabilities of good as well as bad outcomes. For purposes of risk analysis, 
however, the bad outcomes are of main interest. For these reasons, it is absolutely necessary to examine other indicators of stress, including the ratio of interest expense to operating income, the upper percentiles of the distributions of ratios, and, in particular, the very interesting and important simulation results of the authors. Indeed, most of these indicators seem to show that the financial situation of many corporations has worsened in the past few years. In this regard, I was confused by the differences in the simulation results reported in the authors' earlier and present papers. In the earlier paper, 20 percent of the firms encountered solvency problems in the 1973-74 simulation, while the debt-to-asset ratio in the full sample rose from 0.319 in 1986 to 0.962 in recession year 2 . In the present paper, by contrast, 25 percent of the firms encountered solvency problems, while the debt-to-asset ratio for the full sample increased from 0.302 in 1988 to only 0.695 in recession year 2 (table 6). My own work on the solvency issue corresponds more closely to the results of the present paper. It should be noted that 25 percent of the number of firms in the sample becoming insolvent represents, according to my calculations, about 16 percent of corporate assets. In addition, I strongly agree with the authors' statement that the simulations should be viewed only as an indicator of potential vulnerability to financial distress and not as a literal prediction.

I now turn to the evidence the authors present about the three arguments supporting the trend toward higher leverage. I found the authors' evidence on the characterization of debt burden by industry quite convincing; not only has leverage increased in cyclical industries in the past three years, but, counter to intuition, there does not seem to be a negative relationship between the volatility of earnings and leverage. I also found the authors' evidence about the impact of interest rate hedging suggestive of their point that hedging does not prevent financial distress, although a question can be raised: if interest rate hedging does not prevent financial distress, why do so many companies engage in it? A more definitive answer awaits specific information about the hedging activities of companies that should become available upon the adoption of Financial Accounting Standards Board Statement 105 in 1991.

As indicated earlier, I did not find the evidence produced by the authors relating to the leverage-productivity argument persuasive. Aside from the important issue of how to measure an industry's debt burden, whether at historical cost or market value, a more fundamental question is whether industry data and in particular QFR data should be used at all 
to test the proposed argument. The claim that higher leverage improves productivity depends on the hypothesis that management is motivated better to control costs by having debt than by having equity on the company's balance sheet. Because management is specific to a company and not to an industry, however, the argument can be tested only by data from a fixed sample of specific companies or even lines of business. The use of QFR data is particularly questionable given shifts in industry composition owing to mergers and divestitures and the lack of a fixed sample of firms underlying the data.

Despite my objections to certain points in the paper, the authors are to be congratulated for their thorough work on an important topic. I believe that further, larger, and more detailed studies applying the simulation methodology to various economic scenarios would be helpful to our understanding of the risks involved in higher leverage. I also believe it would be fruitful to follow carefully over time the firms in the tails of the distributions or those becoming insolvent or illiquid in the simulations to see if they succumb or how they overcome their problems.

\section{General Discussion}

Joseph Stiglitz noted that observed leverage could change for many reasons. Without an explanation of why debt-equity ratios have changed, it is not possible to evaluate either the extent to which greater leverage indicates increased fragility of the economy or the impact of leverage on productivity. For example, if firms finance lower-risk projects with a higher proportion of debt, higher leverage may simply indicate that firms have undertaken less risky investments. Ben Bernanke responded that most of the firms with dramatic increases in leverage were swapping debt for equity, not making new investments. Stiglitz also noted a difficulty in identifying the effect of changes in leverage on incentives to increase productivity. In firms with rapid productivity growth, equity value will grow rapidly, thus decreasing their measured leverage and masking any effect leverage has on incentives.

Panelists disagreed about other evidence surrounding the relationship between leverage and productivity. Benjamin Friedman cited studies that showed a negative impact of leveraged buyouts on research and development and capital investment expenditures. Martin Baily pointed out that increased debt might improve the productive use of resources even if it led to lower investment in both physical capital and research 
and development. This could be true if such spending had been pushed too far by managers engaged in empire building. Franco Modigliani noted that negative effects of LBOs on productivity should not necessarily be attributed to leverage; LBOs are frequently associated with major changes in the way a firm is managed.

William Brainard raised a variety of questions about the usefulness of industry data in assessing the possibility that increased leverage threatens financial stability. He noted not only that the variance of industry earnings used by the authors understates the average variance of the firms' earnings within the industry, but also that, as the authors point out elsewhere, it is the condition of the most vulnerable firms within the industry that is most important. Idiosyncratic firm risks are relevant to bankruptcy. Similarly, the industry betas, indicating the covariance of the growth in industry earnings with the growth in GNP, are an imperfect measure of the nondiversifiable risks of firms, which is what matters for the valuation of firms and the social risk of bankruptcy. Brainard also noted that other market factors might be useful in assessing these risks. For example, nondiversifiable bankruptcy risk might be expected to depend on the covariance of a firm's earnings or equity value with interest rates. Bernanke suggested that the paper's simulations partially addressed this issue by assessing the sensitivity of the firm's financial condition to interest rate changes.

Franco Modigliani observed that using the nominal interest rate to measure the possibility of liquidity problems understates their actual likelihood. Nominal interest rate declines are frequently associated with both declines in inflation and increases in real interest rates, with the rise in real rates increasing the probability that firms will have liquidity problems. Friedman noted that the equity repurchases appeared much lower in the authors' sample than in the whole economy, suggesting that the authors' results may understate the increased vulnerability of the corporate sector to a financial crunch.

Panelists engaged in a lively discussion about the way the Tax Reform Act of 1986 could have been expected to affect leverage. Modigliani expressed surprise that average leverage has not increased, since the act raised the capital gains tax and thus made debt more attractive. Friedman and Bernanke disagreed, arguing that the corporate tax rate has fallen, making the deductibility of interest payments less important, and that the increase in the effective capital gains tax was less than the statutory increase, since capital gains are largely unrealized. 


\section{References}

Arak, Marcelle, Arturo Estrella, Laurie Goodman, and Andrew Silver. 1988. "Interest Rate Swaps: An Alternative Explanation." Financial Management 17:12-18.

Baker, George P., and Karen H. Wruck. 1990. "Organizational Changes and Value Creation in Leveraged Buyouts: The Case of the O. M. Scott and Sons Company." Working Paper 90-041. Cambridge, Mass.: Harvard Business School.

Bernanke, Ben S., and John Y. Campbell. 1988. "Is There A Corporate Debt Crisis?" BPEA, 1:1988, 83-125.

- 1990. "Recent Trends in Corporate Leverage: Causes and Consequences." In The High Yield Debt Market: Investment Performance and Economic Impact, edited by Edward I. Altman. Homewood, Ill.: DowJones Irwin.

Bicksler, James, and Andrew H. Chen. 1986. "An Economic Analysis of Interest Rate Swaps." Journal of Finance 41:645-55.

Blair, Margaret M., and Robert E. Litan. 1989. "Explaining Corporate Leverage and LBO Activity in the 1980s." Washington: Brookings.

Board of Governors of the Federal Reserve System. 1989. Flow of Funds Accounts: Financial Assets and Liabilities, Year-End, 1965-1988. Washington (September).

Brainard, William C., John B. Shoven, and Laurence Weiss. 1980. "The Financial Valuation of the Return to Capital." BPEA, 2:1980, 453-502.

Gertler, Mark, and R. Glenn Hubbard. 1989. "Taxation, Corporate Capital Structure, and Financial Distress." Working Paper 3202. Cambridge, Mass.: National Bureau of Economic Research (December).

Giammarino, Ronald M. 1989. "The Resolution of Financial Distress." Review of Financial Studies 2:25-47.

Gilson, Stuart C., Kose John, and Larry H. P. Lang. 1989. "Troubled Debt Restructurings: An Empirical Study of Private Reorganization of Firms in Default." University of Texas (November).

Greenspan, Alan. 1989. "Statement before the Committee on Finance, U.S. Senate." Washington: Board of Governors of the Federal Reserve System (January).

Jensen, Michael C. 1989. "Eclipse of the Public Corporation." Harvard Business Review 89:61-74.

Kaplan, Steven N. 1990. "Sources of Value in Management Buyouts." Journal of Financial Economics, forthcoming.

Lichtenberg, Frank R., and Donald Siegel. 1989a. "The Effect of Takeovers on the Employment and Wages of Central-Office and Other Personnel.", Working Paper 2895. Cambridge, Mass.: National Bureau of Economic Research (March).

. 1989b. "The Effects of Leveraged Buyouts on Productivity and 
Related Aspects of Firm Behavior." Working Paper 3022. Cambridge, Mass.: National Bureau of Economic Research (June).

Marais, Laurentius, Katherine Schipper, and Abbie Smith. 1989. "Wealth Effects of Going Private for Senior Securities." Journal of Financial Economics 23:155-91.

Price, John A. M., and Schuyler K. Henderson. 1988. Currency and Interest Rate Swaps, 2nd ed. London: Butterworths.

Roach, Stephen S. 1988. "Living with Corporate Debt." Morgan Stanley Economic Perspectives (November).

Shleifer, Andrei, and Robert W. Vishny. 1988. "Value Maximization and the Acquisition Process." Journal of Economic Perspectives 2:7-20.

Smith, Clifford W., Jr., Charles W. Smithson, and Lee Macdonald Wakeman. 1988. "The Market for Interest Rate Swaps." Financial Management 17:34-44.

Warshawsky, Mark J. 1990. "Is There A Corporate Debt Crisis? Another Look." Washington: Board of Governors of the Federal Reserve System (January). 